\title{
A rose by any other name: het Hof van Justitie stelt grenzen aan controles binnen het Schengengebied
}

\author{
Dr. J.J. Rijpma*
}

In Touring Tours oordeelt het Hof van Justitie dat de verplichting tot het controleren van de verblijfsstatus van internationale buspassagiers binnen het Schengengebied geschaard kan worden onder het begrip (politie)controles binnen het Schengengebied. Hoewel deze in principe zijn toegestaan onder de Schengengrenscode, hebben de controles in casu een effect dat gelijk is aan controles aan de binnengrenzen en zijn daarom in strijd met het Unierecht. Dit artikel plaatst vraagtekens bij de keuze van het Hof van Justitie om de controles aan te merken als politiecontroles en plaatst het arrest in de bredere context van de spanning tussen mobiliteit en veiligheid in de nasleep van de vluchtelingencrisis.

Hvf 13 december 2018, gevoegde zaken C-412/17 en C-474/17, Touring Tours en Sociedad de Transportes, ECLI:EU:C:2018:1005.

\section{Inleiding}

Het vrij reizen binnen de Schengenruimte, ongehinderd door controles aan de binnengrenzen, geldt als een groot goed. Nog geen twintig jaar geleden oordeelde het Hof van Justitie nog dat bij afwezigheid van 'specifieke communautaire regels voor de controles aan de buitengrenzen' Unieburgers om hun reisdocumenten kon worden gevraagd. ${ }^{1}$ Vandaag de dag geldt voor zowel de Unieburger als de derdelander dat hij zich, eenmaal toegelaten tot het Schengengebied, in principe vrij kan bewegen van de Algarve tot aan de poolcirkel.

* Dr. J.J. (Jorrit) Rijpma is universitair hoofddocent Europees Recht verbonden aan het Europa Instituut van de Rechtenfaculteit van de Universiteit Leiden. Hij is tevens Jean Monnet Professor op het gebied van Mobiliteit en Veiligheid in Europe (MOSE).

1. HvJ 21 september 1999, zaak C-378/97, Wijsenbeek, ECLI:EU:C: 1999:439, punt 36.
Toch staat deze verworvenheid, in de nasleep van de vluchtelingencrisis en bij het voortbestaan van terroristische dreiging, onder druk. Met name het vervoer per bus en trein - toegankelijk, goedkoop en anoniem baart hierbij zorgen. ${ }^{2}$ Verschillende lidstaten hebben controles aan de binnengrenzen opnieuw ingevoerd met een beroep op de binnenlandse veiligheid en het tegengaan van zogenoemde secundaire bewegingen, dat wil zeggen het doorreizen van asielzoekers naar andere lidstaten dan de lidstaat die onder de Dublin-verordening verantwoordelijk is voor hun asielaanvraag. ${ }^{3}$ Andere lidstaten hebben het aantal politiecontroles in grensgebieden opgevoerd. ${ }^{4}$ Binnen deze context kijken lidstaten ook naar andere mogelijkheden om irreguliere migratie tegen te gaan.

Het opleggen van sancties aan vervoersondernemingen voor het binnenbrengen van passagiers zonder verblijfstitel is een beproefd, maar ook controversieel instrument voor migratiecontrole. ${ }^{5}$ Het de facto uitbesteden van controles aan private partijen, die plaatsvinden voor het daadwerkelijk bereiken van de grens, past in de trend

2. 'Coach travel in Europe, Revolution on wheels', The Economist 22 oktober 2015; M. van den Eerenbeemt, 'We treinen vaker door Europa, maar vliegen we ook minder?', de Volkskrant 18 december 2018.

3. Verordening (EU) $604 / 2013$ van het Europees Parlement en de Raad van 26 juni 2013 tot vaststelling van de criteria en instrumenten om te bepalen welke lidstaat verantwoordelijk is voor de behandeling van een verzoek om internationale bescherming dat door een onderdaan van een derde land of een staatloze bij een van de lidstaten wordt ingediend, PbEU 2013, L 180/31 ('Dublin III').

4. Zo heeft Nederland in de periode 2015-2018 regelmatig het zogenoemde Mobiel Toezicht Veiligheid (MTV) op grond van art. 4.17a lid 3, 4 en 5 Vreemdelingenbesluit 2000 (Vb 2000) geïntensiveerd. Zie P. Rodrigues en $M$. van der Woude, 'Preventieve politiecontroles en interne grenscontroles in het Schengengebied', Crimmigratie \& Recht 2018, afl. 1, p. 17-29.

5. T. Rodenhauser, 'Another Brick in the Wall: Carrier Sanctions and the Privatization of Immigration Control', International Journal of Refugee Law 2014, afl. 2, p. 223-247; S. Scholten, The Privatisation of Immigration Control through Carrier Sanctions. The Role of Private Transport Companies in Dutch and British Immigration Control, Leiden: Brill 2015. 
van privatisering en externalisering van grensbeleid. ${ }^{6}$ In Duitsland geldt voor vervoersondernemingen die passagiers Duitsland binnenbrengen, een verplichting om te controleren of deze personen in het bezit zijn van een geldig paspoort en waar nodig visum. Dit vloeit voort uit par. 63 van de Duitse Vreemdelingenwet (AufenthG), waarin wordt bepaald dat vervoersondernemingen enkel vreemdelingen Duitsland mogen binnenbrengen die beschikken over een geldige verblijfstitel. ${ }^{7}$ De verplichting zelf is te vinden in punt 63 lid 1 van het Duitse Vreemdelingenbesluit. ${ }^{8}$ Op grond van par. 63 lid 2 AufenthG en punt 63 lid 2 van het Duitse Vreemdelingenbesluit kan aan vervoersondernemingen een vervoersverbod en een dwangsom worden opgelegd bij niet nakoming van deze verplichting. Het grote verschil met vervoerderssancties onder het Unierecht is dat de Duitse maatregelen zien op controles binnen het Schengengebied en op sancties voor het vervoeren van irreguliere migranten over de binnengrenzen. In de gevoegde zaken Touring Tours (C-412/17) en Sociedad de Transportes (C-474/17) vroeg het Bundesverwaltungsgericht, de hoogste federale bestuursrechter van Duitsland, het Hof van Justitie naar de verenigbaarheid met het Unierecht van deze Duitse regelgeving op basis waarvan sancties waren opgelegd aan twee vervoersondernemingen, die lijndiensten per bus verzorgden vanuit andere Schengenlidstaten. Artikel 3 Verdrag betreffende de werking van de Europese Unie (VWEU) bepaalt namelijk dat de Unie een ruimte van vrijheid, veiligheid en recht is zonder binnengrenzen. Dit wordt herhaald in artikel 67 lid 2 VWEU en verder uitgewerkt in artikel 20 Schengengrenscode. ${ }^{9}$ Artikel 21 Schengengrenscode bepaalt dat deze regels de politiebevoegdheid van de lidstaten ongemoeid laten, in zoverre die controles niet hetzelfde effect hebben als grenscontroles. Reeds driemaal eerder werd het Hof van Justitie gevraagd om nationale regelgeving die politiecontroles in de grensstreek toestond te toetsen aan deze bepaling. ${ }^{10}$ Het grote verschil met deze zaken was, dat het hier ging om controles uitgevoerd door private ondernemingen, de busvervoerders, en niet de nationale politie of andere

6. A. Liguori, Migration Law and the Externalization of Border Controls, London: Routledge 2019.

7. Gesetz über den Aufenthalt, die Erwerbstätigkeit und die Integration von Ausländern im Bundesgebiet van 30 juli 2004, BGBI. 2004 I, p. 1950 (hierna: AufenthG).

8. Algemeine Verwaltungsvorschrift zum Aufenthaltsgesetz van 26 oktober 2009, GMBI. 2009, p. 878.

9. Deze artikelen verwijzen naar de Schengengrenscode zoals deze van kracht was ten tijde van de feiten van het hoofdgeding: Verordening (EG) nr. 562/2006 van het Europees Parlement en de Raad van 15 maart 2006 tot vaststelling van een communautaire code betreffende de overschrijding van de grenzen door personen (Schengengrenscode), PbEU 2006, L 105/1. In de nieuwe versie is art. 20 te vinden in art. 22 en art. 21 in art. 23: Verordening (EU) 2016/399 van het Europees Parlement en de Raad van 9 maart 2016 betreffende een Uniecode voor de overschrijding van de grenzen door personen (Schengengrenscode), PbEU 2016, L 77/1.

10. HvJ 22 juni 2010, zaak C-189/10, Melki en Abdeli, ECLI:EU:C: 2010:206, Jur. 2010, p. I-5667; HvJ 19 juli 2012, zaak C-278/12 PPU, Adil, ECLI:EU:C:2012:508; HvJ 21 juni 2017, zaak C-9/16, A.; Europabrug, ECLI:EU:C:2017:483 publieke autoriteit in een andere lidstaat, dan de lidstaat die de controles voorschrijft.

In tegenstelling tot wijlen advocaat-generaal Bot, die concludeerde dat de controles dienen te worden beschouwd als grenscontroles en daarmee verboden zijn onder artikel 20 Schengengrenscode, besloot het Hof van Justitie de controles als politiecontroles binnen het grondgebied van de lidstaat te toetsen aan artikel 21 Schengengrenscode. Aan de hand van criteria die het Hof van Justitie in zijn eerdere jurisprudentie over artikel 21 formuleerde, kwam het tot de conclusie dat de controles hetzelfde effect hadden als grenscontroles en dus niet waren toegestaan.

Dit artikel stelt vraagtekens bij de keuze te toetsen aan artikel 21 Schengencode. Hoewel het Hof van Justitie hiermee het toetsingskader uit eerdere rechtspraak kan toepassen, doet het daarmee geen recht aan de complexiteit van het delegeren van overheidstaken aan private partijen en het fenomeen waarbij grenscontroles allang niet meer enkel aan de fysieke grens zelf plaatsvinden. Artikel 20 verbiedt grenscontroles aan de binnengrenzen tenzij deze voor beperkte duur gerechtvaardigd kunnen worden op grond van openbare orde of binnenlandse veiligheid. ${ }^{11}$ Dit artikel beoogt tevens het arrest in de bredere context te plaatsen van de roep van de lidstaten om meer controlebevoegdheden om problemen van openbare veiligheid en irreguliere migratie aan te pakken. Mobiliteit binnen de Schengenruimte wordt daarmee in steeds belangrijker mate geproblematiseerd als een veiligheidsvraagstuk.

\section{Casus}

Touring Tours en Sociedad de Transportes zijn beide touringcaroperators die lijndiensten onderhouden naar Duitsland vanuit andere lidstaten. Het Bundespolizeipräsidium (het presidium van de Duitse federale politie) waarschuwde beide bedrijven dat zij zich schuldig maakten aan het op grote schaal binnenbrengen van vreemdelingen die niet in bezit waren van de vereiste reisdocumenten, in strijd met par. 63 lid 1 AufenthG. $\mathrm{Nu}$ aan deze waarschuwing geen gehoor werd gegeven, werd een vervoersverbod opgelegd, vergezeld van een dwangsom van 1000 euro voor iedere nieuwe inbreuk. De vervoerders hadden bij het instappen de documenten van passagiers moeten controleren en hadden bij gebreke aan deze documenten de betreffende passagiers dienen te weigeren. De bestuursrechter in eerste aanleg (Verwaltungsgericht) vernietigde in de beroepsprocedure de beschikkingen, omdat op grond van de voorrang van het Unierecht de Duitse regels die ten grondslag lagen aan de beschikking buiten toepassing dienden te worden gelaten, vanwege strijd met artikel 67 lid 2 VWEU en artikel 20 en 21 Schengengrenscode. De controles moesten naar het oordeel van de rechter in eerste

11. Zie voor de regels ten aanzien van het herinvoeren van controles aan de binnengrenzen Titel III, hoofdstuk II van de Schengengrenscode (art. 25 e.v.; art. 23 e.v. in de versie van 2006). 
aanleg namelijk worden aangemerkt als maatregelen met hetzelfde effect als grenscontroles in de zin van artikel 21 Schengencode.

De Bondsrepubliek Duitsland stelde beroep (Revision) in bij de verwijzende rechter (Bundesverwaltungsgericht). Ten eerste zouden regels van het Unierecht die zien op bestrijding van illegale migratie - in het bijzonder Richtlijn 2002/90/EG en Kaderbesluit 2002/946/JBZ - verplichten tot het strafbaar stellen van het vervoeren van irreguliere migranten, net als het Palermo-protocol tegen mensensmokkel. ${ }^{12}$ Daarnaast zouden de controles niet hetzelfde effect hebben als grenscontroles omdat het doel ervan niet controle van grensoverschrijding zou zijn, maar het naleven van de regels over binnenkomst op het grondgebied. ${ }^{13}$ Bovendien zouden de reikwijdte en intensiteit van de controles geringer zijn dan van grenscontroles, nu deze niet door overheidspersoneel worden uitgevoerd, daardoor minder grondig zouden zijn, en bovendien niet kunnen resulteren in dwang- of opsporingsmaatregelen.

Het Bundesverwaltungsgericht stelde prejudiciële vragen die er in de woorden van het Hof van Justitie op neerkwamen of artikel 67 lid 2 VWEU en artikel 20 en 21 Schengengrenscode zich verzetten tegen nationale wetgeving als in de hoofdgedingen aan de orde. Meer specifiek wilde de verwijzende rechter weten of de controles dienden te worden aangemerkt als controles aan de binnengrenzen, verboden door artikel 20 Schengengrenscode of als politiecontroles, in principe toegestaan onder artikel 21 sub a, mits deze niet hetzelfde effect sorteren als grenscontroles. Daarnaast wenste de verwijzende rechter te vernemen of artikel 21 sub b, dat veiligheidscontroles in luchthavens en havens toestaat, voor zover deze ook worden toegepast op reizigers binnen de lidstaat, in de weg staat aan controles door vervoersondernemingen die geen veiligheidscontrole zijn en niet op reizigers binnen de lidstaat worden uitgeoefend.

12. Richtlijn 2002/90/EG van de Raad van 28 november 2002 tot omschrijving van hulpverlening bij illegale binnenkomst, illegale doortocht en illegaal verblijf, PbEU 2002, L 328/17; Kaderbesluit 2002/946/JBZ van de Raad van 28 november 2002 tot versterking van het strafrechtelijk kader voor de bestrijding van hulpverlening bij illegale binnenkomst, illegale doortocht en illegaal verblijf, PbEU 2002, L 328/1; Palermo Smokkelprotocol, zie annex bij Besluit 2006/619/EG van de Raad van 24 juli 2006 betreffende de sluiting, namens de Europese Gemeenschap, van het Protocol inzake de voorkoming, bestrijding en bestraffing van mensenhandel, in het bijzonder vrouwenhandel en kinderhandel, tot aanvulling van het Verdrag van de Verenigde Naties tegen grensoverschrijdende georganiseerde misdaad met betrekking tot de bepalingen van het protocol voor zover deze onder deel III, titel IV, van het Verdrag tot oprichting van de Europese Gemeenschap vallen, PbEU 2006, L 262/51

13. Dit lijkt een verwaarloosbaar verschil, maar het Hof van Justitie accepteerde eerder in de arresten Adil (punt 64) en A.; Europabrug (punt 47) dat politiecontroles het bestrijden van illegaal verblijf na grensoverschrijding tot doel kunnen hebben zonder daarmee hetzelfde effect als grenscontroles te sorteren.

\section{Uitspraak van het Hof van Justitie}

Het Hof van Justitie beperkt zich in zijn antwoord enkel tot een analyse van de verenigbaarheid van de controles met artikel 67 lid 2 VWEU en artikel 20 en 21 Schengengrenscode, nu de verwijzende rechter in zijn prejudiciële vragen niet naar andere instrumenten van Unierecht verwees. Het is staande rechtspraak dat de verwijzende rechter de omvang van de prejudiciële vraagprocedure bepaalt. ${ }^{14}$ Wel voegt het Hof van Justitie in een obiter toe dat een eventuele verplichting tot het invoeren van vervoerderssancties die voortvloeit uit andere EUregelgeving of internationaal recht ten uitvoer dient te worden gelegd in het kader van de Schengengrenscode. ${ }^{15}$ Het is niet geheel duidelijk waarom de Schengengrenscode hierbij als leidend wordt gezien, maar dit kan eventueel worden verklaard door deze te zien als de uitwerking van de verdragsnorm neergelegd in artikel 3 Verdrag betreffende de Europese Unie (VEU) en artikel 67 lid 2 VWEU.

Het Hof van Justitie oordeelt dat artikel 20 Schengengrenscode niet van toepassing is, omdat de controles niet 'aan de grenzen' worden verricht of 'bij overschrijding van de grens', maar op het grondgebied van een lidstaat. ${ }^{16}$ Het Hof van Justitie wijkt hier af van de conclusie van de advocaat-generaal, die van mening is dat wel degelijk sprake is van grenscontroles. De advocaat-generaal komt tot dat oordeel op grond van de interpretatie die het Hof van Justitie in de Affum-zaak gaf aan het begrip 'het op niet reguliere wijze overschrijden over land, over zee of door de lucht' in artikel 2 lid 2 sub a Terugkeerrichtlijn. ${ }^{17}$ Het Hof van Justitie oordeelde in die zaak dat dit een 'rechtstreeks temporeel en ruimtelijk verband' met het daadwerkelijk oversteken van de grens veronderstelt. ${ }^{18}$ Het valt echter - zoals de advocaatgeneraal lijkt te hebben geredeneerd - te beargumenteren dat ook bij rechtstreekse lijndiensten over de binnengrens sprake is van ononderbroken temporeel en ruimtelijk verband, waarbij de controle bij instappen een vooruitgeschoven grenscontrole vormt, en dat enkel die controle aan de fysieke overschrijding van de grens in de weg staat. ${ }^{19}$ Wel spreekt tegen een dergelijke interpreta-

14. HvJ 13 december 2018, gevoegde zaken C-412/17 en C-474/17, Touring Tours en Sociedad de Transportes, ECLI:EU:C:2018:1005, punt 39 en 41 en de daarin vermelde jurisprudentie.

15. Touring Tours en Sociedad de Transportes, punt 43

16. Touring Tours en Sociedad de Transportes, punt 45.

17. Conclusie A-G Y. Bot 6 september 2018, gevoegde zaken C-412/17 en C-474/17, Touring Tours en Sociedad de Transportes, ECLI:EU:C: 2018:671, punt 83; HvJ 7 juni 2016, zaak C-47/15, Affum, ECLI:EU:C: 2016:408; Richtlijn 2008/115/EG van het Europees Parlement en de Raad van 16 december 2008 over gemeenschappelijke normen en procedures in de lidstaten voor de terugkeer van onderdanen van derde landen die illegaal op hun grondgebied verblijven (Terugkeerrichtlijn), PbEU 2008, L 348/98

18. Affum, punt 72 .

19. Conclusie A-G Bot, Touring Tours en Sociedad de Transportes, punt 86. Ter vergelijking: niemand zal ontkennen dat de vooruitgeschoven grenscontroles in Brussel/Parijs alvorens het aan boord gaan van de Eurostar naar Londen als grenscontroles dienen te worden aangemerkt. 
tie dat het Hof van Justitie eveneens in de Affum-zaak expliciet oordeelde dat een derdelander die in een autobus over het grondgebied van een lidstaat reist, zich op het grondgebied van die lidstaat bevindt, ook wanneer het een directe lijnverbinding over de buitengrens betreft (Gent-Londen). ${ }^{20}$ Die benadering kan echter verklaard worden vanuit het feit dat bij een andere interpretatie de waarborgen van de Terugkeerrichtlijn niet van toepassing zouden zijn, terwijl de persoon in kwestie wel degelijk reeds irregulier verbleef binnen de Schengenruimte en deze probeerde te verlaten.

Voor het Hof van Justitie is dus doorslaggevend dat de controles binnen het grondgebied van een lidstaat plaatsvinden. Vervolgens dient het artikel 21 sub a van toepassing te verklaren op controles die worden uitgeoefend door private ondernemingen die niet over openbaar gezag beschikken. Artikel 21 sub a spreekt immers enkel van 'politiebevoegdheden uitgeoefend door de bevoegde instanties van de lidstaten' en 'politiële maatregelen'. Het Hof van Justitie is van mening dat, nu de controleverplichting een wettelijke basis heeft, de vervoersonderneming deze uitoefent op het gezag en onder toezicht van instanties die wel over politiële bevoegdheden beschikken. ${ }^{21}$ Hier kan de vraag gesteld worden of de enkele mogelijkheid tot het opleggen van een sanctie bij het achterwege laten van deze verplichting, wel kan worden aangemerkt als gezag over en toezicht op de uitoefening van deze controles. De advocaat-generaal verwijst in zijn conclusie naar rechtspraak van het Franse Grondwettelijk Hof van Justitie waaruit volgt dat vervoerderssancties niet kunnen worden uitgelegd, als ware aan de vervoerders een politiebevoegdheid verleend. ${ }^{22}$ Ook volgens de verwijzende rechter is hier geen sprake van. Tegelijkertijd merkt het Hof van Justitie terecht op dat indien controles door private partijen niet zouden vallen binnen de reikwijdte van deze bepaling, het nuttig effect ervan teniet zou worden gedaan. ${ }^{23}$

Nieuw is dat het Hof van Justitie ook controles die niet worden uitgeoefend op het eigen grondgebied, maar binnen dat van een andere lidstaat, binnen het toepassingsbereik van artikel 21 sub a brengt. De tekst van de bepaling zelf laat daar zeker ruimte voor, maar het roept wel de fundamentele vraag op in hoeverre lidstaten politiële bevoegdheden mogen (laten) uitoefenen op het grondgebied van een andere lidstaat. Hoewel in het huidig tijdsgewricht waarschijnlijk geen enkele lidstaat bezwaar zou maken tegen het uitvoeren van additionele migratiecontroles, kan worden beargumenteerd dat er geen extraterritoriale werking kan worden toegekend aan politiebevoegdheden, zeker omdat de eindverantwoordelijkheid voor binnenlandse veiligheid op grond van artikel 4 lid 2 VWEU nog altijd bij de individuele lidstaten ligt.

Het Hof van Justitie makt duidelijk dat er - in tegenstelling tot bij veiligheidscontroles, zoals die zijn toegestaan onder artikel $21 \mathrm{sub} b-$ geen vereiste is dat de controles voorgeschreven door par. 63 lid 2 AufenthG ook worden toegepast op reizigers binnen de lidstaat. ${ }^{24}$ In Adil bepaalde het Hof van Justitie al dat artikel 21 sub b zijn eigen werkingssfeer en toepassingsvoorwaarden kent en dat onder artikel 21 sub a controles in de grensstreek niet op dezelfde wijze op de rest van het grondgebied hoeven te worden toegepast. ${ }^{25}$ Hieruit volgt dat het Hof van Justitie de controles in ieder geval niet als veiligheidscontroles ziet. ${ }^{26}$

Artikel 21 sub a bevat een viertal aanwijzingen die erop kunnen duiden dat er geen sprake is van politiecontroles met een gelijke werking als grenscontroles. Dit is het geval wanneer de controles geen grenstoezicht tot doel hebben, gebaseerd zijn op algemene politie-informatie en -ervaring en gericht zijn tegen grensoverschrijdende criminaliteit, niet systematisch zijn en plaatsvinden op basis van 'spot-checks'. Uit de jurisprudentie van het Hof van Justitie in Melki en Abdeli, Adil en $A$. volgt dat indien er wel sprake is van een van deze factoren, nationale wetgeving dient te voorzien in voldoende nauwkeurige en gedetailleerde toelichtingen en beperkingen op de controlebevoegdheid, met name ten aanzien van intensiteit, frequentie en selectiviteit. ${ }^{27}$ Naarmate er meer aanwijzingen zijn, dienen deze beperkingen strikter te zijn en strikter in acht te worden genomen. ${ }^{28}$

Ook in deze zaak zijn er volgens het Hof van Justitie meerdere aanwijzingen dat de Duitse controleverplichting en de daaraan verbonden sanctieregeling niet in overeenstemming zijn met artikel 21 sub a. Allereerst wordt met grenscontroles onder de Schengengrenscode beoogd zekerheid te verkrijgen dat de personen het grondgebied van de lidstaat mogen binnenkomen dan wel verlaten, en voorts te voorkomen dat personen zich aan deze controles onttrekken. ${ }^{29} \mathrm{Nu}$ de controles enkel tot doel hebben te verzekeren dat de personen aan boord van de bus aan de voorwaarden voor toelating voldoen, zijn zij dus gericht op grenstoezicht. Ten tweede zijn de controles van een algemeen karakter, van toepassing op alle busverbindingen, en niet gebaseerd op specifieke politie-informatie ten aanzien van mogelijke bedreigingen van de openbare orde. ${ }^{30}$ Ten derde worden de controles stelselmatig uitgevoerd. Dat de controles door de vervoersmaatschappijen waarschijnlijk minder grondig van aard zullen zijn, doet daar volgens het Hof van Justitie niet aan af. ${ }^{31}$ Ten vierde onderscheidt de territoriale werkingssfeer van de controles zich duidelijk van de
20. Affum, punt 49

21. Touring Tours en Sociedad de Transportes, punt 49

22. Conclusie A-G Bot, Touring Tours en Sociedad de Transportes, punt 97.

23. Touring Tours en Sociedad de Transportes, punt 50. Een parallel kan worden getrokken met de zaak Fra.bo (HvJ 12 juli 2012, zaak C-171/11, Fra.bo, ECLI:EU:C:2012:453), waar Duitse wetgeving rechtsgevolgen verbond aan certificering door private partijen, die het vrij verkeer van goederen schond.
24. Touring Tours en Sociedad de Transportes, punt 51.

25. Adil, punt 73

26. Touring Tours en Sociedad de Transportes, punt 52.

27. Touring Tours en Sociedad de Transportes, punt 54, onder verwijzing naar deze eerdere zaken: Melki en Abdeli, Adil en A.; Europabrug.

28. Touring Tours en Sociedad de Transportes, punt 54.

29. Touring Tours en Sociedad de Transportes, punt 58-59.

30. Touring Tours en Sociedad de Transportes, punt 60-61

31. Touring Tours en Sociedad de Transportes, punt 62-64. 
politiecontroles in grensgebieden, zoals die aan de orde waren in eerdere zaken over de verenigbaarheid van politiecontroles met artikel 21 sub a, door de nauwe band met de overschrijding van de binnengrens. ${ }^{32}$ Ten slotte is ook de rechtsgrondslag van de controles een andere dan die van controles op vergelijkbare busverbindingen binnen Duitsland. ${ }^{33}$ Zoals het Hof van Justitie eerder aangaf, moet die omstandigheid meegewogen worden in de 'globale beoordeling' van het effect van de controles. ${ }^{34}$

Het Hof van Justitie geeft niet aan hoe de verschillende aanwijzingen tegen elkaar dienen te worden afgewogen, maar concludeert dat 'de opgesomde aanwijzingen, met een beoordeling van het relatieve belang ervan', alsmede het ontbreken van specifieke regelgeving die de controles beperkt in intensiteit, frequentie en selectiviteit tot de conclusie moet leiden dat de controles hetzelfde effect als grenscontroles hebben. ${ }^{35}$ Een nationale controleverplichting, zoals die is neergelegd in par. 63 lid 1 AufenthG, is daarmee in strijd met het Unierecht, net als de daaraan verbonden sanctiebepaling. Beargumenteerd kan worden dat de motivering van het Hof van Justitie ook de benadering van de advocaat-generaal zou hebben kunnen ondersteunen. Het Hof van Justitie erkent immers expliciet dat de controles grenstoezicht tot doel hebben en daarnaast een 'bijzonder nauwe band hebben met de overschrijding van de binnengrens' ${ }^{36}$ Zelfs al had de Duitse regering in dat geval overtuigend aangevoerd dat de Duitse maatregelen gerechtvaardigd waren op grond van openbare orde, dan nog zouden de controles strijdig met Unierecht zijn geweest, aangezien de herinvoering daarvan enkel tijdelijk van aard mag zijn en gebonden is aan strikte procedurele regels. ${ }^{37}$

\section{De conclusie van de advocaat-} generaal

De conclusie van de advocaat-generaal verdient om meerdere redenen nadere lezing. In de eerste plaats omdat hij in zijn evaluatie van de passagierscontroles als vooruitgeschoven grensposten een aantal ethische en juridische problemen aanstipt, die het Hof van Justitie door de controles te kwalificeren als politiecontroles weet te omzeilen.

De advocaat-generaal verwijst in zijn conclusie naar het fenomeen dat de fysieke grens en de plek waarmee het individu met de grens wordt geconfronteerd, niet langer samenvallen. ${ }^{38}$ In literatuur spreekt men ook wel van

35. Touring Tours en Sociedad de Transportes, punt 71. De Nederlandse vertaling spreekt abusievelijk tweemaal van intensiteit.

36. Touring Tours en Sociedad de Transportes, punt 68.

37. Zie voor de regels ten aanzien van het herinvoeren van controles aan de binnengrenzen Hoofdstuk II van de Schengengrenscode (art. 25 e.v.; art. 23 e.v. in de versie van 2006).

38. Conclusie A-G Bot, Touring Tours en Sociedad de Transportes, punt 86. 'remote policing' of de 'extra-territorialisering' van controles. ${ }^{39}$ Het klassieke voorbeeld hiervan zijn de vervoerderssancties als voorzien in de Schengen Uitvoeringsovereenkomst en Richtlijn 2001/51/EG. ${ }^{40}$ In zijn beoordeling van de controles door busmaatschappijen als vooruitgeschoven controles aan de binnengrenzen, is de advocaat-generaal uitermate kritisch ten opzichte van dit fenomeen. Hij beoordeelt de Duitse regeling zelfs als 'laakbaar vanuit het oogpunt van bepaalde grondrechten, zoals het recht op asiel, zoals neergelegd in artikel 18 van het Handvest'. ${ }^{41} \mathrm{Hij}$ is die mening toegedaan, omdat geen onderscheid wordt gemaakt tussen irreguliere migranten en asielzoekers. ${ }^{42}$ Dit gaat echter tegen de logica van de Dublin-verordening en de Schengenregels in, waarbij dit onderscheid binnen de Schengenruimte niet langer relevant zou moeten worden geacht.

De kritiek van de advocaat-generaal wint aan kracht wanneer deze wordt toegepast op controles door vervoerders buiten het Schengengebied. Hoewel de Richtlijn Vervoerderssancties zegt dat vervoerders deze toe moeten passen zonder afbreuk te doen aan het recht op asiel, is het effect in de praktijk dat iemand zonder visum niet per georganiseerd vervoer de Europese Unie kan bereiken. ${ }^{43}$ Als bovendien deze vooruitgeschoven controles ook zouden moeten worden aangemerkt als grenscontroles, zou daarmee het toepassingsbereik van de Schengengrenscode, inclusief de daarin vervatte waarborgen, aanmerkelijk worden vergroot. ${ }^{44}$ Daarnaast behelst de kritiek van de advocaat-generaal niet alleen het naar voren halen van grenscontroles, maar ook de uitvoering daarvan door private partijen. De advocaatgeneraal merkt ten aanzien hiervan op dat vervoerders hiermee worden geacht taken uit te voeren die onder de bevoegdheid van douane- of politieautoriteiten vallen, terwijl zij 'hiertoe noch over de bekwaamheid, noch over de benodigde middelen beschikken'. ${ }^{45}$

Een tweede reden om aandacht te besteden aan de conclusie van de advocaat-generaal is omdat deze een illustratie vormt van de huidige discussie over 'Schengen governance', waarin vragen van openbare orde (migratiecontrole) samenkomen met vragen van binnenlandse veiligheid (terroristische dreiging). De advocaat-generaal concludeert dat de vervoerderscontroles zoals voor-

39. D. Bigo en E. Guild, 'Policing at Distance: Schengen Visa Policies', in: D. Bigo en E. Guild, Controlling Frontiers, Aldershot: Ashgate 2005, p. 234; J.J. Rijpma en M. Cremona, The Extra-Territorialisation of EU Migration Policies and the Rule of Law, EUI Working Papers LAW 2007/01, p. 11

40. Richtlijn 2001/51/EG van de Raad van 28 juni 2001 tot aanvulling van het bepaalde in artikel 26 van de Overeenkomst ter uitvoering van het Akkoord van Schengen van 14 juni 1985, PbEU 2001, L 187/45.

41. Conclusie A-G Bot, Touring Tours en Sociedad de Transportes, punt 20.

42. Conclusie A-G Bot, Touring Tours en Sociedad de Transportes, voetnoot 14

43. Richtlijn 2001/51/EG, overweging 3 .

44. A-G P. Mengozzi noemde in zijn conclusie van 17 april 2012, zaak C-355/10, Europees Parlement/Raad; Frontex, ECLI:EU:C:2012:207, punt 70 , de vraag naar de werkingssfeer van de waarborgen neergelegd in art. 13 van de Schengengrenscode een gevoelige, die waarschijnlijk in de toekomst aan het Hof van Justitie zou worden voorgelegd.

45. Conclusie A-G Bot, Touring Tours en Sociedad de Transportes, punt 98. 
geschreven in de Duitse regelgeving, een niet-toegestane herinvoering van controles aan de binnengrenzen vormen. Hij benadrukt dat lidstaten over voldoende andere instrumenten beschikken om illegale migratie naar hun grondgebied te voorkomen. ${ }^{46}$ Toch is het nog maar de vraag of de maatregelen die de advocaat-generaal aandraagt een volwaardig en, zoals door hem wordt gesteld, doeltreffender alternatief vormen. ${ }^{47}$

De advocaat-generaal wijst in de eerste plaats op de verplichting van lidstaten om samen te werken met het oog op een doeltreffend toezicht aan de buitengrenzen en de verplichting van lidstaten om een hoog niveau van grenstoezicht aan de buitengrenzen te waarborgen. ${ }^{48}$ In het geval van falend toezicht aan de buitengrenzen kunnen lidstaten allereerst op basis van artikel 21 Schengengrenscode politiecontroles op het grondgebied van de lidstaten en binnen het grensgebied van de lidstaten uitvoeren. ${ }^{49}$ Dit is ook de benadering die de Commissie voorstaat in haar recente aanbeveling. ${ }^{50}$

Ten tweede wijst hij op de mogelijkheden tot het strafbaar stellen van vervoerders voor het meewerken aan migrantensmokkel, op grond van Richtlijn 2002/90/EG en Kaderbesluit 2002/946/JBZ, zoals die in Duitsland zijn omgezet in par. 95 tot en met 97 AufenthG. ${ }^{51}$

Als laatste wijst de advocaat-generaal erop dat controles aan de binnengrenzen tijdelijk kunnen worden hervat in geval van een serieuze bedreiging van de openbare orde of binnenlandse veiligheid. Hij verwijst daarmee in eerste instantie naar artikel 23 lid 1 Schengengrenscode dat toestaat controles aan de binnengrenzen tijdelijk te hervatten op basis van een serieuze bedreiging voor de openbare orde of binnenlandse veiligheid. ${ }^{52}$ Overigens kan dit op basis van artikel 26bis Schengengrenscode, wanneer de bedreiging het gevolg is van serieuze tekortkomingen in het beheer van de buitengrenzen, zelfs voor een periode van twee jaar. ${ }^{53}$ Meerdere lidstaten handhaven op dit moment de herinvoering van hun buitengrenzen voor cumulatieve periodes langer dan die waarin de Schengengrenscode voorziet. Naast de overwegingen van binnenlandse veiligheid die gelieerd zijn aan een voortdurende terroristisch dreiging, wordt daarbij met name gewezen op zogenoemde 'secundaire bewegingen' in de nasleep van de vluchtelingencrisis. ${ }^{54}$

46. Conclusie A-G Bot, Touring Tours en Sociedad de Transportes, punt 106.

47. Conclusie A-G Bot, Touring Tours en Sociedad de Transportes, punt 109.

48. Conclusie A-G Bot, Touring Tours en Sociedad de Transportes, punt 108.

49. Conclusie A-G Bot, Touring Tours en Sociedad de Transportes, punt 112.

50. Conclusie A-G Bot, Touring Tours en Sociedad de Transportes, punt 113; zie Commissie Aanbeveling, 12 mei 2017, betreffende evenredige politiecontroles en politiële samenwerking in het Schengengebied, C(2017)3349 def.

51. Conclusie A-G Bot, Touring Tours en Sociedad de Transportes, punt 114.

52. Huidig art. 25 lid 1 Schengengrenscode

53. Huidig art. 29 Schengengrenscode.

54. Zie voor een overzicht: European Commission, 'Temporary Reintroduction of Border Control', https://ec.europa.eu/home-affairs/what-wedo/policies/borders-and-visas/schengen/reintroduction-bordercontrol_en (laatst bezocht 1 juli 2019).
De vraag is in hoeverre het zich onttrekken aan de bepalingen van de Dublin-verordening vandaag de dag nog kan worden aangemerkt als het gevolg van een serieuze tekortkoming in het toezicht van de buitengrenzen of een serieus gevaar voor de openbare orde. De EU-wetgever bepaalde eerder dat de toestroom van grote aantallen derdelanders niet per se een serieuze bedreiging voor de openbare orde hoeft te zijn, al accepteerde de Commissie op het hoogtepunt van de crisis wel dat de ongecontroleerde toestroom van derdelanders zonder verblijfsdocumenten hieronder kon worden geschaard. ${ }^{55}$ Interessant is in dit verband ook de verwijzing van de advocaat-generaal naar het voorstel tot wijziging van de Schengengrenscode, waaronder een herinvoering van controles aan de binnengrenzen ook zou worden toegestaan in geval van serieuze bedreigingen voor de openbare orde of binnenlandse veiligheid die losstaan van tekortkomingen in het toezicht aan de buitengrenzen. In dit voorstel wordt expliciet gerefereerd aan secundaire bewegingen. ${ }^{56}$ Het aanmerken van secundaire bewegingen als een grond voor herinvoering laat zien hoezeer in het publieke en politieke discours mobiliteit en veiligheid met elkaar verweven zijn geraakt.

De conclusie van de advocaat-generaal verdient ten slotte aandacht, omdat hij in tegenstelling tot het Hof van Justitie wel de argumenten van de Duitse regering behandelt, waarmee werd betoogd dat overige maatregelen van Europees en internationaal recht de vervoerderssancties toestonden, of zelfs voorschreven. Vanuit het standpunt van de ontwikkeling van het Europees strafrecht is met name de autonome en eenvormige uitlegging die de advocaat-generaal geeft aan het woord 'opzettelijk' in artikel 1 lid 1 sub a interessant. Hij is van mening dat het niet voldoen aan de controleverplichting niet gelijk kan worden gesteld aan hulpverlening bij illegale binnenkomst op grond van Richtlijn 2002/90/EG en Kaderbesluit 2002/946/JBZ. Naar de mening van de advocaat-generaal vereist deze term dat iemand 'willens en wetens' hulp verleent bij illegale binnenkomst en is deze niet van toepassing op iemand die uit nalatigheid het risico neemt. ${ }^{57}$ De term sluit daarmee 'voorwaardelijk' opzet uit. Dit is een andere invulling dan bijvoorbeeld in het Nederlands strafrecht aan het opzetbegrip wordt gegeven, waarbij het bewust aanvaarden van een aanmerkelijke kans dat een bepaald gevolg zal intreden geschaard wordt onder het begrip voorwaarde-

55. Verordening (EU) nr. 1051/2013 van het Europees Parlement en de Raad van 22 oktober 2013 tot wijziging van Verordening (EG) nr. 562/2006 teneinde te voorzien in gemeenschappelijke regels inzake de tijdelijke herinvoering van het grenstoezicht aan de binnengrenzen in uitzonderlijke omstandigheden, PbEU 2013, L 295/1, overweging 5; Commissie Advies, 23 oktober 2015, over de noodzakelijkheid en evenredigheid van de herinvoering van het grenstoezicht aan de binnengrenzen door Duitsland en Oostenrijk overeenkomstig artikel 24, lid 4, van Verordening nr. 562/2006 (Schengengrenscode), C(2015)7100 def.

56. Commissievoorstel tot wijziging van Verordening (EU) 2016/399 wat betreft de regels die van toepassing zijn op de tijdelijke herinvoering van het grenstoezicht aan de binnengrenzen, $\operatorname{COM}(2017) 571$ def., p. 7.

57. Conclusie A-G Bot, Touring Tours en Sociedad de Transportes, punt 142 . 
lijk opzet. ${ }^{58}$ Zeker nu de Duitse autoriteiten de vervoerders in kwestie hadden gewaarschuwd kan worden beargumenteerd dat hier sprake van was. ${ }^{59}$ Ook voor strafbaarheid onder par. 96 AufenthaltG geldt dat voorwaardelijk opzet (dolus eventualis of bedingter Vorsetz) voldoende is. ${ }^{60}$ Overigens wijst de advocaat-generaal er terecht op dat deze bepaling in Duits recht is omgezet in par. 95-97 AufenthaltG, en dus niet in de bepalingen die voorwerp vormden van de prejudiciële vraagprocedure. De advocaat-generaal concludeert ten slotte dat noch het Palermo-protocol, noch maatregelen van secundair Unierecht het instellen van vervoerderssancties verplicht stellen, dan wel toelaten. ${ }^{61}$

\section{Slotoverwegingen}

In Touring Tours bepaalt het Hof van Justitie dat de verplichting tot het uitvoeren van controles door private vervoerdersmaatschappijen binnen de Schengenruimte dient te worden beschouwd als een vorm van politiecontroles binnen het grondgebied van de lidstaten in plaats van vooruitgeschoven grenscontroles. Bij toetsing aan criteria die het Hof van Justitie in zijn eerdere rechtspraak over politiecontroles in de grensstreek ontwikkelde, oordeelde het Hof van Justitie dat deze controles hetzelfde effect hebben als grenscontroles. Daarmee wordt het onderscheid tussen artikel 20 en artikel 21 enigszins arbitrair. Beargumenteerd kan worden dat de Uniewetgever in de Schengengrenscode in het geheel niet had voorzien in dit type controle. Daarmee zou een toetsing aan het algehele verbod op grenscontroles, een benadering die ansluit bij de conclusie van de advocaat-generaal, zuiverder zijn geweest.

Deze zaak toont aan dat het vrij reizen over de binnengrens in de nasleep van de vluchtelingencrisis nog altijd onder druk staat. De mogelijkheden die de Schengengrenscode biedt om door middel van het herinvoeren van controles aan de binnengrenzen en het uitvoeren van politiecontroles tegemoet te komen aan de zorgen van de lidstaten ten aanzien van de openbare orde en binnenlandse veiligheid worden door de lidstaten klaarblijkelijk als onvoldoende beschouwd. Het Hof van Justitie is hier tot nog toe in zijn rechtspraak ten aanzien van artikel 21 Schengengrenscode ontvankelijk voor gebleken. In deze zaak trekt het echter de grens; een conclusie die gezien het praktisch effect van de vervoerderscontroles gerechtvaardigd is.

Ondertussen wordt op Unieniveau op verschillende manieren geprobeerd tegemoet te komen aan de zorgen van de lidstaten. Enerzijds door het aannemen van wet-

58. J. de Hullu, Materieel Strafrecht, Deventer: Kluwer 2015, p. 234 e.v

59. Overigens is deze bepaling in het Nederlands strafrecht in art. 197a Wetboek van Strafrecht omgezet, waarbij reeds het bestaan van ernstige redenen om te vermoeden dat toegang of doorreis wederrechtelijk is (culpa) voldoende is om strafbaarheid aan te nemen.

60. U. Hohoff, 'AufenthG § 96 Einschleusen von Ausländern', in: A. Heusch en W. Kluth, BeckOK Ausländerrecht, München: C.H. Beck 2019.

61. Conclusie A-G Bot, Touring Tours en Sociedad de Transportes, punt 153 en 164 . geving die specifiek gericht is op het vergroten van de veiligheid van reizen naar en binnen de Schengenruimte. Gedacht moet daarbij worden aan de verplichting tot het uitwisselen van PNR-gegevens (passenger name record) door luchtvaartmaatschappijen; een verplichting die door de lidstaten kan worden uitgebreid - en dat in de praktijk ook zonder uitzondering wordt - tot intraEU-vluchten. ${ }^{62}$ Verwacht kan worden dat in de toekomst meer voorstellen worden gedaan, zoals de uitbreiding van de uitwisseling van PNR-gegevens tot andere vormen van internationaal verkeer, of invoering van een identificatieplicht op vluchten. ${ }^{63}$

Anderzijds heeft de Uniewetgever gezocht naar aanvullende manieren om irreguliere migratie tegen te gaan. De hervorming en aanscherping van de Dublin-verordening zien grotendeels op het tegengaan van secundaire bewegingen. ${ }^{64}$ Het Europees Grens- en Kustwachtagentschap moet de bescherming van de buitengrenzen versterken en krijgt daarnaast onder zijn nieuwe mandaat ook de bevoegdheid deze bewegingen te monitoren. ${ }^{65}$ In Brussel gaan stemmen op om serieuze tekortkomingen in de toepassing van de Dublin-regels als zelfstandige reden te zien voor het voor langere tijd herinvoeren van de Schengenregels. Enige logica zit daar wel in, nu beide regelgevende kaders kunnen worden beschouwd als flankerende maatregelen voor het goed functioneren van de Schengenruimte. ${ }^{66}$

De Commissie adviseert lidstaten in haar aanbevelingen ook in te zetten op het gebruik van technologie. ${ }^{67}$ Nederland gebruikt sinds een antal jaar het zogenoemde 'Amigo-Boras systeem', een camerasysteem boven de snelwegen dat werkt met automatische nummerplaatherkenning. Beargumenteerd zou kunnen worden dat vanuit de doelstelling van de Schengensamenwerking, namelijk een ongehinderde doorstroom over de binnengrenzen, dergelijke vormen van controle een te verwaarlozen beperking vormen van het recht op vrij reizen. ${ }^{68}$ Het lijkt hoe dan ook onvermijdelijk dat er, in anvulling op een versterking van de buitengrenzen, in de nabije toekomst meer aandacht zal worden besteed aan maatregelen die binnen de Schengenruimte genomen kunnen worden. In deze zaak heeft het Hof van Justitie laten zien dat het dergelijke maatregelen - ook in de

62. Richtlijn (EU) 2016/681 van het Europees Parlement en de Raad van 27 april 2016 over het gebruik van persoonsgegevens van passagiers (PNR-gegevens) voor het voorkomen, opsporen, onderzoeken en vervolgen van terroristische misdrijven en ernstige criminaliteit, PbEU 2016, L 119/132.

63. A. Korteweg, 'Plan voor meer controle op reizen per bus, trein en boot' de Volkskrant 4 januari 2017.

64. $\operatorname{COM}(2016) 270$ def., p. 4

65. Raadsdocument 8354/19, 9 april 2019, art. 27.

66. De verdragen van de EU met de Schengen Associatielanden (IJsland, Noorwegen, Zwitserland en Liechtenstein) verbinden de toepassing van de Schengenregels aan de toepassing van de Dublin-regels waaraan deze landen eveneens met bilaterale verdragen zijn verbonden.

67. Commissie Aanbeveling, 12 mei 2017, betreffende evenredige politiecontroles en politiële samenwerking in het Schengengebied, C(2017)3349 def., punt 1 sub d.

68. Zie echter voor kritiek op de veronderstelde objectiviteit van dit systeem: T. Dekkers, M. van der Woude en R. Koulish, 'Objectivity and accountability in migration control using risk assessment tools', European Journal of Criminology 2019, afl. 2, p. 237-254. 
nasleep van de vluchtelingencrisis - niet kritiekloos zal accepteren. Voor de uitkomst in deze zaak maakte het niet uit of de Duitse maatregelen dienden te worden aangemerkt als politiecontroles of als vooruitgeschoven grenscontroles: 'a rose by any other name' kan nog altijd onaangenaam ruiken. 